\title{
Eğitim ve Araştırma Hastanesinde Çalışan Hemşirelerin Kesici-Delici Tıbbi Aletleri Güvenli Kullanımlarına ílişkin Farkındalıkları
}

\author{
Awareness Regarding Safe Use Of Sharp-Edged Medical Instruments Among Nurses \\ In Training And Research Hospital
}

\author{
Selen Özakar Akça ${ }^{1}$, Zehra Aydın \\ 1 Hitit Üniversitesi Sağlık Yüksekokulu, Çorum
}

\section{OZET}

Amaç: Kesici-delici tıbbi alet yaralanmaların en fazla hemşirelerde görülmesi, onların daha çok farkındalıklarının artırılmasının önemini ortaya koymaktadır. Çalışmamızda Eğitim ve Araştırma Hastanesinde (EAH) görev yapan hemşirelerin kesici-delici tıbbi aletleri (KDTA) güvenli kullanımlarına ilişkin farkındalıklarının ölçülmesi ve bu konu ile ilgili yapılması planlanan eğitim programına temel oluşturması amaçlanmıştır.

Gereç ve Yöntem: Çalışma Hitit Üniversitesi EAH görev yapan ( $N=365)$ hemşirelerde tanımlayıcı ve kesitsel tipte yapılmıştır. Araştırmada örneklem seçimine gidilmemiş, çalışmanın yapıldığ tarihler arasında (15.02/15.05.15) görev yapan hemşireler araştırmanın örneklemini $(n=259)$ oluşturmuştur. Araştırma verileri hemşirelerin tanımlayıcı özelliklerini belirlemeye yönelik ve "Sağlık Çalışanlarının KDTA Güvenli Kullanımına Yönelik Tutum Ölçeği" sorularını içeren anket formu kullanılarak toplanmıştır. Araştırma verileri uygun istatistiksel yöntemlerle değerlendirilmiştir. $p<0.05$ istatistiksel olarak anlamlı kabul edilmiştir.

Bulgular: Hemşirelerin "Sağlık Çalışanlarının KDTA Güvenli Kullanımına Yönelik Tutum Ölçeği"nden aldıkları toplam puan $70.26 \pm 11.65$ 'dur. Araştırmaya katılan > 5 yıl çalışan hemşirelerin bilişsel, duyuşsal ve davranışsal alt ölçek puan ortalamalarının $\leq 5$ yıl çalışanlara göre daha yüksek olduğu belirlenmiş olup, bu farkın istatistiksel olarak ileri düzeyde anlamlı olduğu $(p<0.01)$ görülmüştür.

Sonuç: Araştırmadan elde ettiğimiz sonuçlar doğrultusunda, hemşirelerin neredeyse tamamının (93.1\%) "KDTA yaralanmaları ile ilgili eğitim" aldığı görülmüştür. Fakat $\leq 5$ yıl çalışan personelin ölçek puan ortalamalarının düşük çıkması, onların daha sık ve düzenl eğitim almasının önemini ortaya koymaktadır. Ülkemizde hasta ve çalışan güvenliği konusunun gelişmesinde önemli rol oynayan kesicidelici tıbbi aletlerin güvenli kullanımına yönelik çalışmalara gereksinim bulunmaktadır.

Anahtar Kelimeler: Tıbbi Aletler, yaralanmalar, hemşire, eğitim

Corresponding Author: Selen ÖZAKAR AKÇA,

Address: Hitit Üniversitesi Sağlık Yüksekokulu, Çorum, Türkiye.

E-mail: selenozakar@hotmail.com

Phone: +90 36422307 32-3513

\section{ABSTRACT}

Objective: The fact that sharp-edged medical instrument injuries are mostly seen among nurses demonstrates the importance of increasing their awareness about this topic. With this present study it is intended to measure the awareness regarding safe use of sharpedged medical instrument of nurses working in Training and Research Hospitals and to create the basis for the training program planned to be provided on this topic.

Method: This descriptive and cross-sectional type study was conducted on nurses $(N=365)$ working in the Training and Research Hospital of Hitit University. No sample selection was made, the sample consisted of nurses $(n=259)$ working during the dates of the study (15.02/15.05.15). Research data has been collected through an "Attitude Scale of Health Care Workers to Safe Use of Sharp-Edged Medical Instrument" questionnaire and characteristics of participants defining questions. Research data has been evaluated with appropriate statistical methods. $p<0.05$ has been accepted as statistically significant.

Results: The total score obtained by nurses from the "Attitude Scale of Health Care Workers to Safe Use of Sharp-edged Medical Instruments" was $70.26 \pm 11.65$. It was determined that the cognitive, affective and behavioral subscale point averages of $>5$ years working nurses who participated in the study are higher compared to nurses working $\leq 5$ years. This difference was observed as being statistically significant at an advanced level $(p<0.01)$.

Conclusions: It was found that almost all of the nurses (93.1\%) received training about "Sharp-Edged Medical Instrument Injuries", however the sufficient and desired level of knowledge as a result of this training has not been reached. The low subscale point averages of personnel working $\leq 5$ years reveals the importance of receiving more frequent and regular education. Studies regarding safe use of sharpedged medical instruments are needed as they play an important role regarding patient and employee safety in our country.

Key words: medical instruments, injuries, nurse, training
Başvuru Tarihi/Received: 20-03-2016

Kabul Tarihi/Accepted: $\quad$ 16-04-2016 


\section{GiRiş}

Sağıık çalışanları, uyguladıkları tedavi ve bakım girişimleri nedeniyle özellikle kan yolu ile bulaşan bazı hastalıklara maruz kaldıklarından risk grubu olarak görülmektedir $(1,2)$. Sağlık personellerinin mesleki nedenlerle enfekte kan ve vücut sıvılarıyla karşı karşıya kalmaları sonucu hepatitler ve AIDS (Edinilmiş İmmun Yetersizlik Sendromu) gibi önemli mortalite ve morbiditeye neden olabilen enfeksiyon hastalıklarına yakalanmaları kaçınılmazdır $(3,4)$.

Kanla taşınan enfeksiyonlar açısından kesici ve delici alet yaralanmaları ile sağlık çalışanlarına 20 farklı patojen ajanın bulaşabileceği, mukokütanöz yaralanmalara oranla perkütan yaralanmalarda enfeksiyonların bulaşma riskinin daha yüksek olduğu bildirilmiştir $(2,3,5)$. Kesici ve delici alet; elle tutulduğu sırada cildin penetran yaralanmasına neden olabilen tıbbi ya da laboratuvar ekipmanları (iğneler, sivri uçlu intravenöz giriş araçları, bisturi, lanset, pipet ya da ampullere ait kırık cam parçaları ve enjektörler) olarak tanımlanmaktadır $(1,4)$.

Hastalık Kontrol ve Önleme Merkezi (Centers for Disease Control and Prevention, $(D C)$ 'nin tahminlerine göre hastane çalışanlarında her yıl 385 bin enjektör yaralanması ve günde ortalama 1000 kesici alet yaralanması olmakta, kan ve vücut sıvılarına maruz kalma şeklinde oluşan yaralanmaların en fazla hemşirelerde olduğu bildirilmektedir $(6,7)$. Avrupa iş̧ Sağlığı ve Güvenliği Ajansı (European Agency for safety and Health at Work, EU-OSHA)'ya göre Avrupa'da her yıl 1 milyon enjektör yaralanması olmaktadır (2). Ülkemizde ise hemşirelik öğrencilerinin ve hemşirelerin hastaya bakım verirken enfekte kişi ve taşıyıcılarından HBV (hepatit B virüsü) aldıkları saptanmış $(1,4)$, sağlık personelinde HBV infeksiyon sıklığının, diğer mesleklere göre 3-6 kat daha fazla olduğu bildirilmiştir $(8,9,10)$. Günümüzde tek kullanımlık tıbbi malzemelerin tercih edilmesi, vakumlu tüple kan alma, delici ve kesici aletlerin delinmez enfekte atık kutusuna atılması gibi yaklaşımlarla perkütan yaralanmaların oranı önemli ölçüde azalmakla beraber ülkemizde halen yüksek oranda olup, önemini korumaktadır $(1,11)$. Ayrıca elde edilen veriler kesici-delici tıbbi alet yaralanmalarının yetersiz rapor edildiğini göstermektedir $(4,10,12)$

1987 yılında CDC çalışanları korumak için evrensel önlemleri yayınlayıp bu önlemlerin sağlığın korunması için zorunluluk olduğunu, bu önlemler alındığında HBV, HCV (hepatit C virüsü) ve HIV bulaşma riskinin de azaldığını, sağıık çalışanlarında kesici-delici tıbbi aletlerin kullanımında dikkatli olmanın ve önlem almanın yaralanmaları azaltacağını vurgulamıştır $(2,10,13)$. Ülkemizde de son yıllarda ulusal sağlık politikaları kapsamında, Sağlıkta Hizmet Kalite Standartları düzeyi artarak devam etmektedir. Sağlık Bakanlığı Sağlık Hizmetleri Genel Müdürlüğü tarafından yürütülen "Hasta ve Çalışan Güvenliği" çalışmaları son derece önem taşımaktadır (1).

Ulusal ve uluslar arası yapılan çalışmalar $(2,10,11,12)$ sağıık çalışanlarının kesici-delici tıbbi aletleri güvenli kullanımında tam ve yeterli olmadıklarını göstermekte, kesici-delici tıbbi alet yaralanmalarının en fazla hemşirelerde görülmesi, onların daha çok farkındalıklarının artırılmasının önemini ortaya koymaktadır. Ayrıca enfekte olan ve serolojisi pozitif olan sağlık çalışanlarının uyguladıkları tedavi ve bakım girişimleri ile hastalara bu virüsleri bulaştırmaları olasılığı, Hepatit, AIDS'in etkin bir tedavisinin olmaması ve prognozlarının ciddi seyretmesi konunun önemini arttırmakta $(1,3)$, "Hasta ve Çalışan Güvenliği" konusunu gündeme getirmektedir.

Çalışmamızda Eğitim ve Araştırma Hastanesinde görev yapan hemşirelerin kesicidelici tıbbi aletleri (KDTA) güvenli kullanımlarına ilişkin farkındalıklarının ölçülmesi ve bu konu ile ilgili yapılması 
planlanan eğitim programına temel oluşturması amaçlanmıştır.

\section{GEREÇ ve YÖNTEM}

Çalışma Hitit Üniversitesi Eğitim ve Araştırma Hastanesinde görev yapan ( $N=365)$ tüm hemşirelerde kesitsel tipte yapılmıştır. Araştırmada örneklem seçimine gidilmemiş olup, çalışmanın yapıldığı tarihler arasında (15.02/15.05.15) görev yapan ve araştırmaya gönüllü olarak katılmak isteyen $(n=259)$ hemşireler araştırmanın örneklemini oluşturmuştur. Örneklem hacminin yeterliliğini belirlemek için yapılan güç analizinde 0.05 önemlilik düzeyinde \%95 güven aralığında çalışmanın gücünün $\% 80$ olduğu belirlendi. Bu sayı örneklem hacminin yeterli olduğunu göstermektedir.

Çalışmaya başlamadan önce kurum izni (02.02.2015/71444544-258) ve Ankara Numune Eğitim ve Araştırma Hastanesi Klinik Araştırmalar Etik Kurulundan (29.01.2015/ E15-399) onay alınmıştır. Ayrıca araştırmaya katılmaya gönüllü olan hemşirelere araştırmanın amacı ile ilgili bilgi verilerek yazılı onam alınmıştır.

Araştırmada veri toplama aracı olarak anket formu kullanılmıştır. $\mathrm{Bu}$ form; araştırmacı, uzman görüşleri ve literatür bilgileri doğrultusunda geliştirilmiştir. Araştırma verileri, hemşireler tarafından, araştırmacıların gözetiminde toplam 10 dakikalık bir süre içinde doldurmaları sonucu elde edilmiştir. Anket formu, iki bölümden oluşmaktadır. Birinci bölümde; hemşirelerin tanımlayıcı özellikleri (yaş, cinsiyet, mezun olduğu okul, çalıştığı bölüm, toplam çalışma süresi, HBV'ye karşı aşılanma ve KDTA yaralanmaları ile ilgili eğitim durumu), ikinci bölümde ise Uzunbayır (11) tarafından geliştirilen ve güvenilirlik geçerliliği yapılmış olan (Cronbach alfa=0.80) "Sağlık Çalışanlarının Kesici-Delici Tıbbi Aletleri (KDTA) Güvenli Kullanımına Yönelik Tutum Ölçeği" kullanılmıştır. Ölçekte; toplamda 25 madde yer almakta ve bilişsel, duyuşsal, davranışsal tutumu belirleyen üç alt bölüm bulunmaktadır. Her bir sorunun cevabını değerlendirmede 1 ile 5 puan arasında değişen likert tipi puanlama kullanılmaktadır. Toplam ölçekten alınabilecek en yüksek puan 125, en düşük puan 25, bilişsel alt ölçek puanı türünde alınabilecek maksimum puan 60 , minimum puan 12 , duyuşsal alt ölçek puanı türünde alınabilecek maksimum puan 30, minimum puan 6 ve davranışsal alt ölçek puanı türünde alınabilecek maksimum puan 35 , minimum puan 7'dir. Ölçeğin kesme puanı hesaplanmamış, alınan puan arttıkça kesicidelici tıbbi aletlerin güvenli kullanıldığını göstermektedir $(1,11)$.

Hemşirelerin cinsiyeti, mezun olduğu okul, çalıştığı bölüm, toplam çalışma süresi, HBV'ye karşı aşılanma ve KDTA yaralanmaları ile ilgili eğitim durumu bağımsız, hemşirelerin "Sağlık Çalışanlarının KDTA Güvenli Kullanımına Yönelik Tutum Ölçeği”nden aldıkları puan ise bağımlı değişken olarak alınmıştır.

Araştırma sonucunda elde edilen verilerin değerlendirilmesi bilgisayar ortamında, SPSS (Stastistical Package for Social Science) 21 paket programında $t$ testi ve varyans analizi kullanılarak değerlendirilmiştir. $\quad \mathrm{p}<0.05$ istatistiksel olarak anlamlı kabul edilmiştir.

Araştırmanın sınırılıkları; araştırmanın yapıldığı tarihlerde izinde olan, nöbetten çıkan ve çalışmaya katılmak istemeyen hemşirelerin olmasından dolayı evrenin \% 70.96'sına ulaşıımasıdır. Bu çalışmada sadece Hitit Üniversitesi Eğitim ve Araştırma Hastanesinde görev yapan hemşirelerin kesici-delici tıbbi aletleri güvenli kullanımlarına ilişkin farkındalıkları değerlendirilmiştir. Ayrıca çalışmadan elde edilen veriler hemşirelerin sorulara verdikleri cevaplarla sınırlıdır.

\section{BULGULAR}

Araştırmaya katılan hemşirelerin yaş ortalaması $34.12 \pm 8.60$ 'dır. Hemşirelerin büyük 
çoğunluğunun (\% 78) kadın ve \% 23.6'sının yüksek lisans mezunu olduğu belirlenmiştir. Araştırmadaki hemşirelerin büyük çoğunluğunun (\% 64.9) cerrahi kliniklerinde çalıştıkları, \% 74.5'inin 5 yıldan fazla çalıştığı, \% 15.8'inin HBV'ye karşı aşılanmadığı ve \% 6.9'unun "KDTA yaralanmaları ile ilgili eğitim" almadığı görülmektedir (Tablo 1).

Araştırmaya katılan hemşirelerin "Sağlık Çalışanlarının KDTA Güvenli Kullanımına Yönelik Tutum Ölçeği" nden aldıkları toplam puan $70.26 \pm 11.65$ (min: 31; max: 105) olarak belirlenmiştir. Hemşirelerin cinsiyeti, çalıştığı bölüm, HBV'ye karşı aşılanma ve bu konu ile ilgili eğitim alma durumları ile ölçekten alınan puan arasında istatistiksel olarak anlamlı fark olmadığı $(p>0.05)$ görülmüştür. Çalışmaya

Tablo 1. Hemşirelerin Tanımlayıcı Özelliklerine Göre Dağılımı ve "Sağlık Çalışanlarının Kesici-Delici Tıbbi Aletleri Güvenli Kullanımına Yönelik Tutum Ölçeği”nden Aldıkları Puanların İncelenmesi (N=259)

\begin{tabular}{|c|c|c|c|}
\hline Özellikler & n (\%) & 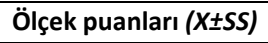 & Istatistiksel Analiz \\
\hline \multicolumn{4}{|l|}{ Cinsiyet } \\
\hline Kadın & $202(78.0)$ & $70.60 \pm 11.72$ & $t=48.925$ \\
\hline Erkek & $57(22.0)$ & $69.03 \pm 11.43$ & $p=0.670$ \\
\hline \multicolumn{4}{|l|}{ Mezun olunan okul } \\
\hline Ön lisans & $99(38.2)$ & $64.57 \pm 7.15$ & $f=186.353$ \\
\hline Lisans & $99(38.2)$ & $66.03 \pm 7,40$ & $p=0.000^{*}$ \\
\hline Yüksek Lisans ve üstü & $61(23.6)$ & $86.36 \pm 8.05$ & \\
\hline \multicolumn{4}{|l|}{ Çalıştığı Birim } \\
\hline Dahili klinik & $91(35.1)$ & $69.71 \pm 11.72$ & $t=63.313$ \\
\hline Cerrahi klinik & $168(64.9)$ & $70.55 \pm 11.64$ & $p=0.159$ \\
\hline \multicolumn{4}{|l|}{ Toplam çalışma süresi } \\
\hline$\leq 5$ & $66(25.5)$ & $67.74 \pm 9.89$ & $t=83.262$ \\
\hline$>5$ & $193(74.5)$ & $77.63 \pm 13.27$ & $p=0.000^{*}$ \\
\hline \multicolumn{4}{|c|}{ HBV'ye karşı aşılanma durumu } \\
\hline Evet & $218(84.2)$ & $70.27 \pm 11.54$ & $t=69.876$ \\
\hline Hayır & $41(15.8)$ & $70.19 \pm 12.36$ & $p=0.072$ \\
\hline \multicolumn{4}{|c|}{$\begin{array}{l}\text { "Kesici-delici tıbbi alet yaralanmaları" ile ilgili eğitim alma } \\
\text { durumu }\end{array}$} \\
\hline Evet & $241(93.1)$ & $74.05 \pm 15.25$ & $\mathrm{t}=70.331$ \\
\hline Hayır & $18(6.9)$ & $69.97 \pm 11.33$ & $p=0.067$ \\
\hline \multirow{2}{*}{ YAŞ } & En büyük & En küçük & $X \pm S S$ \\
\hline & 18 & 60 & $34.12 \pm 8.60$ \\
\hline
\end{tabular}

Tablo 2. Hemşirelerin Eğitim Durumlarına Göre "Sağlık Çalışanlarının Kesici-Delici Tıbbi Aletleri Güvenli Kullanımına Yönelik Tutum Ölçeği”nden Aldıkları Puanların İncelenmesi (N=259) katılan hemşirelerin eğitim ve toplam çalışma süreleri ile ölçekten alınan toplam puan arasında istatistiksel olarak anlamlı fark olduğu $(p<0.05)$ belirlenmiştir (Tablo 1$)$.

Araştırmaya katılan ön lisans ve lisans mezunu hemşirelerin bilişsel, duyuşsal ve davranışsal alt ölçek puanlarının yüksek lisans ve üstü eğitimi olanlara göre daha düşük olduğu belirlenmiştir. Hemşirelerin eğitim durumları ile bilişsel, duyuşsal ve davranışsal alt ölçek puanları arasında istatistiksel olarak ileri düzeyde anlamlı fark olduğu $(p<0.01)$ görülmüştür (Tablo 2). 
Kesici-Delici Tıbbi Aletleri Güvenli Kullanımına Yönelik Tutum Ölçeği Alt

Boyutları $(X \pm S S)$

\begin{tabular}{cccc}
\cline { 2 - 4 } Mezun Olunan Okul & $\begin{array}{c}\text { Bilişsel } \\
(12-60)\end{array}$ & $\begin{array}{c}\text { Duyuşsal } \\
(6-30)\end{array}$ & $\begin{array}{c}\text { Davranışsal } \\
(7-35)\end{array}$ \\
\hline Ön Lisans & $28.33 \pm 3.55$ & $14.60 \pm 2.36$ & $21.63 \pm 2.88$ \\
\hline Lisans & $29.10 \pm 4.16$ & $14.87 \pm 2.87$ & $22.05 \pm 2.55$ \\
\hline Yüksek Lisans ve Üstü & $39.72 \pm 5.93$ & $21.72 \pm 3.89$ & $24.91 \pm 3.43$ \\
\hline TOPLAM & $31.30 \pm 6.44$ & $16.38 \pm 4.19$ & $22.56 \pm 3.18$ \\
\hline İstatistiksel analiz & $\mathrm{f}=6.513$ & $\mathrm{f}=11.708$ & $\mathrm{f}=3.970$ \\
& $\mathrm{p}=0.000^{*}$ & $\mathrm{p}=0.000^{*}$ & $\mathrm{p}=0.000^{*}$ \\
\hline Not: One- way Anova *p $<0.01$ & & &
\end{tabular}

Not: One- way Anova, *p $<0.01$

Araştırmaya katılan > 5 yıl çalışan hemşirelerin bilişsel, duyuşsal ve davranışsal alt ölçek puan ortalamalarının $\leq 5 \mathrm{yıl}$ çalışanlara göre daha yüksek olduğu belirlenmiş olup, bu farkın istatistiksel olarak ileri düzeyde anlamlı olduğu $(p<0.01)$ görülmüştür (Şekil 1).

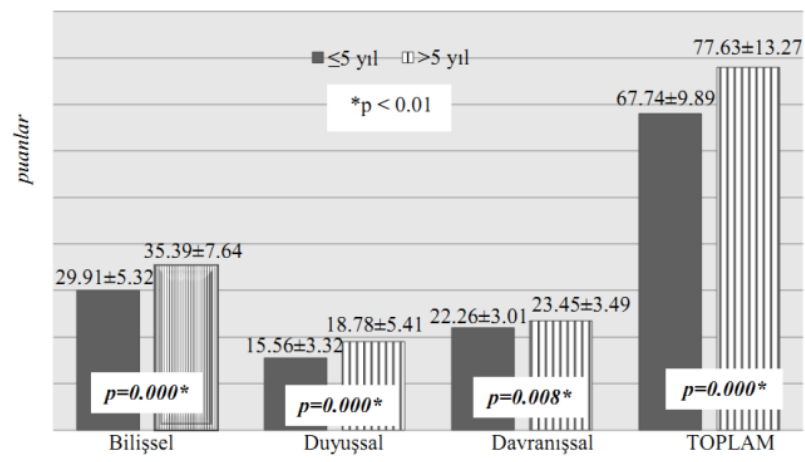

Sağlık Çalıșanlarının Kesici-Delici Tıbbi Aletleri Güvenli Kullanımına Yönelik Tutum Ölçeği Alt Boyutları

Şekil 1. Hemşirelerin Toplam Çalışma Sürelerine Göre "Sağlık Çalışanlarının Kesici-Delici Tıbbi Aletleri Güvenli Kullanımına Yönelik Tutum Ölçeğì”nden Aldıkları Puanların İncelenmesi

( $\mathrm{N}=259)$

\section{TARTIŞMA}

Kan yolu ile bulaşan bazı hastalıklar açısından sağlık çalışanları önemli bir risk grubu olarak kabul edilmektedir. Bu hastalıklardan özellikle hepatitlerin ve AIDS'in etkin bir tedavisinin olmaması ve prognozlarının ciddi seyretmesi konunun önemini arttırmakta, sağlık çalışanlarımızın içinde bulunduğu riski ve KDTA yaralanma ihtimaline karşı alınması gereken önlemlerin gerekliliğini tanımlamaktadır $(1,3)$.

Perkütan yaralanmalar hemşirelerde diğer meslek gruplarından daha fazla görülmektedir. Bunun nedeni olarak, hemşire başına düşen hasta sayısının fazla olmasından dolayı işlerini aceleyle yapmaları, erken yaşta mesleğe başlama, yoğun ve uzun çalışma saatleri, bakım, tedavi, IV kanül takma, kan alma ve malzemelerin temizliği gibi birden çok işlemden sorumlu olma ve yetersiz organizasyonun olduğu bildirilmektedir $(2,8,14,15)$. Bu sonuçlar doğrultusunda araştırmamızın örneklem grubunu sağlık çalışanları arasında kan ile bulaşan ajanlarla karşılaşma olasılığı en yüksek olan hemşirelerin oluşturması önemlidir.

Kesici-delici tıbbi alet yaralanmaları ile ilgili yapılan çalışmalarda $(16,17,18)$ araştırma grubunu oluşturan hemşirelerin büyük çoğunluğunun kadın olduğu ve yaş

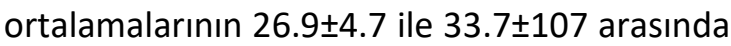
değiştiği bildirilmiştir. Ayrıca hemşireler arasında genel olarak \% 18.1 olan delici kesici alet yaralanma oranının, cerrahi birimlerde çalışan hemşirelerde \% 70-\% 75 düzeyinde olduğu ve sağlık çalışanlarından iş deneyimi $\leq$ 5 yıl olanların, iş deneyimi > 5 yıl olanlara göre yaralanma oranının yüksek olduğu belirtilmektedir $\quad(2,18,19)$. Çalışmamızda 
örneklemin \% 78'ini kadınların oluşturması ve yaş ortalamalarının $34.12 \pm 8.60$ olması hemşirelerin genel özelliklerini yansıtmaktadır. Araştırmamızda hemşirelerin büyük çoğunluğunun (\% 64.9) cerrahi birimlerde çalışması ve yaklaşık 1/4'ünün $\leq 5$ yıldan çalışıyor olması örneklem grubundakilerin teşhis, tedavi ve bakım hizmetlerini verirken kullandığı KDTA güvenli kullanım tutumlarının ölçülmesinin önemini ortaya koymaktadır (Tablo 1).

Yapılan çalışmalarda hemşirelerin HBV aşısı olma sıklıklarının yüksek olduğu bildirilmiştir $\quad(2,16,20)$. Çalışmamızda literatürle benzer şekilde hemşirelerin büyük çoğunluğunun (\% 84.2) HBV aşısının olması sevindiricidir (Tablo 1). Hemşireler arasında aşılanma oranlarının yüksek olarak belirlenmesi, 1987 yılından itibaren CDC'nin nerede çalıştığına bakılmaksızın tüm sağlık çalışanlarına hepatit $B$ aşısını önermesi ve EUOSHA tarafından 1991 yılında yayınlanan "Bloodborne Pathogens Standard"ta hepatit B aşısının mesleki maruziyete uğrama ihtimali yüksek olan sağlık çalışanlarına işveren tarafından yapılmasının zorunlu hale getirilmesi gösterilebilir (2).

Yapılan çalışmalarda $(2,20)$ hastanede çalışan personellerin genel olarak KDTA yaralanmaları ile ilgili eğitim alma oranları düşük olmakla birlikte, bu oranın hemşirelerde yüksek olduğunun görülmesi, kurumdaki en düzenli hizmet-içi eğitimlerin hemşire grubuna ait olduğunu göstermektedir. Çalışmamızda ise diğer sağlık çalışanları yer almadığı için bu konuda karşılaştırma yapılamamıştır. Fakat hemşirelerin bu konu ile ilgili eğitim alma oranının \% 93.1 olması, kurumdaki hizmet-içi eğitimlerin düzenli yürüdüğünü göstermektedir (Tablo 1).

Sağlık çalışanlarının kesici-delici aletleri güvenli kullanımlarının incelendiği 2011 yılında Yıldız tarafından yapılan çalışmada lisans eğitimi almış olanların "Sağılık Çalışanlarının Kesici-Delici Tıbbi Aletleri Güvenli Kullanımına
Yönelik Tutum Ölçeği" toplam puan ortalamasının yüksek lisans ve ön lisans mezunlarına göre yüksek olduğu bildirilmiştir. Bilişsel, duyuşsal ve davranışsal alt ölçek puan türlerinden en yüksek puan ortalamasını lisans mezunu hemşirelerin aldığı görülmüş olmasına rağmen eğitim durumu ile toplam ölçek ve alt ölçekleri arasında istatistiksel açıdan anlamlı fark bulunmamıştır (21). Çalışmamızda Yıldız'ın (21) çalışmasının aksine yüksek lisans ve üstü mezunu olan hemşirelerin ölçekten aldıkları puan ortalamalarının $(86.36 \pm 8.05)$ lisans $(66.03 \pm 7,40)$ ve ön lisans mezunu olanlara (64.57 \pm 7.15$)$ göre yüksek olduğu görülmüş, bilişsel, duyuşsal ve davranışsal alt ölçek puan türlerinden en yüksek puan ortalamasını yüksek lisans ve üstü hemşirelerin aldığı belirlenmiştir (Tablo 1). Çalışmamıza katılan hemşirelerin eğitim durumu ile toplam ölçek ve alt ölçek puan ortalamaları arasında istatistiksel açıdan ileri düzeyde anlamlı fark olduğu $(p<0.01)$ saptanmıştır (Tablo 1; Tablo 2). Çalışmamızda yüksek lisans ve üstü eğitim alan hemşirelerin ölçek puan ortalamalarının yüksek çıkması sevindiricidir ama bu konuda lisans ve ön lisans mezunu hemşirelerin daha fazla eğitime intiyaç duyduklarını ve aldıkları bu bilgiyi davranış haline dönüştürmeleri gerektiğini düşündürmektedir.

Yapılan araştırmalarda $(2,17,22,23)$ cerrahi birimlerde çalışan sağlık personellerinin KDTA yaralanma oranları daha yüksek olarak bildirilmiştir. Dolayısıyla cerrahi birim hemşirelerinin tutumlarının diğer birimlere göre farklı olması beklenmektedir. Çalışmamızda literatürle uyumlu olarak, cerrahi kliniğinde çalışan hemşirelerin farkındalığının dahili branşlara oranla daha yüksek olduğu belirlenmiştir. Ancak hemşirelerin çalıştığı bölüm ile ölçek puanı arasında istatistiksel açıdan anlamlı fark olmadığı görülmüştür. $\mathrm{Bu}$ durum riskli alanlarda çalışan hemşirelerde KDTA yaralanması konusunun daha fazla önemsenmiş olabileceğini ve tutumun 
davranışa dönüştüğünü düşündürmektedir (Tablo 1).

Mesleki profesyonellik, mesleki standartların belirlenmesinde ve hizmet kalitesinin yükseltilmesinde önemli yer tutmaktadır. Mesleki profesyonellik yani deneyim her meslekte önemlidir fakat sağlık çalışanlarında daha da önemli olduğu bildirilmektedir $(1,24)$. Yapılan çalışmalarda sağlık çalışanlarının KDTA yaralanmalarına olan tutumu deneyim artışı ile pozitif yönde geliştiği, sağılık çalışanlarında iş deneyimi arttıkça kesici-delici alet yaralanmalarının azaldığı gösterilmiştir $(1,5,25)$. Yacoub ve ark. (25) > 5 yıldan deneyimi olan sağlık çalışanlarının daha az deneyimi olanlara göre KDTA yaralanması yaşama olasılı̆ıııı daha düşük olduğunu bildirmiştir. Özyiğit ve ark. (1) da meslekte beş yılını dolduran hemşire grubunda KDTA yaralanması konusunda farkındalıklarının daha yüksek olduğunu belirtmiştir. Çalışmamızda toplam çalışma süresi $\leq 5$ yıl olan hemşirelerin $>5$ yıl olanlara göre toplam ölçek puan ortalamalarının düşük olduğunun görülmesi literatürle uyumlu olduğunu göstermektedir (Şekil 1). Bu sonuç meslekte deneyimin ne kadar önemli olduğunu vurgulamaktadır.

Sağıık çalışanları arasında aşılanma oranları oldukça yüksektir $(16,17,18,20)$. Çalışmamızda da aşılanma oranları yüksek bulunmuştur (\% 84.2; Tablo 1). Aşılanma oranının yüksek olması, bu konu hakkında olumlu bir tutum geliştiğini düşündürmektedir. Ayrıca çalışmamızda KDTA yaralanmaları hakkında eğitim almış hemşirelerin ölçekten aldıkları puan ortalamalarının eğitim almayanlara göre yüksek olduğu belirlenmiştir (Tablo 1). Bu bulgular verilen eğitimlerin hemşirelerin bu konudaki bilincini artırdığını göstermekte, hemşirelerin eğitim yoluyla KDTA yaralanmaları konusunda bilinçlenmeleri, tutum geliştirdiklerini ve davranışa dönüştürdüklerini düşündürmektedir.

\section{SONUÇ Ve ÖNERILER}

Araştırmadan elde ettiğimiz sonuçlar doğrultusunda, hemşirelerin neredeyse tamamının (93.1\%) "KDTA yaralanmaları ile ilgili eğitim" aldığı görülmüştür. Fakat $\leq 5$ yıl çalışan personelin ölçek puan ortalamalarının düşük çıkması, onların daha sık ve düzenli eğitim almasının önemini ortaya koymaktadır. Ayrıca hemşirelerin çalışma sürelerine ve yaşlarına bakılmaksızın "KDTA yaralanmaları" konusundaki eğitimlerin periyodik olarak yapılmasının gerekliliği dikkat çekmektedir.

Ülkemizde hasta ve çalışan güvenliği konusunun gelişmesinde önemli rol oynayan kesici-delici tıbbi aletlerin güvenli kullanımına yönelik çalışmalara gereksinim bulunmaktadır. Sağlık çalışanlarının KDTA yaralanmaları sebebiyle maruz kaldıkları riskleri en aza indirmek, bu konudaki tutum ve davranışlarını geliştirmek amacıyla, kurum politikalarının olması, gerekli önlemlerin alınması, hizmet içi uygulamalı eğitim programlarının düzenlenmesi ve belirli periyotlarda tekrarlanması önerilmektedir.

\section{KAYNAKLAR}

1. Özyiğit F, Küçük A, Altuntaş Ö, Arıkan i, Kumbasar $\mathrm{H}$, Fener $\mathrm{S}$, et al. Bir Eğitim ve Araştırma Hastanesinde görev yapan sağlık çalışanlarının kesicidelici tıbbi aletleri güvenli kullanımına yönelik tutumları. Haseki Tıp Bülteni 2014;52:168-71.

2. Turan $\mathrm{H}$, Togan $\mathrm{T}$. Hastane personelinde görülen kan ve vücut sıvılarıyla ilişkili yaralanmaların değerlendirilmesi. Klimik Dergisi 2013;26(3):98-101.

3. Dement JM, Epling C, Ostbye T, Pompeii LA, Hunt DL. Blood and body fluid exposure risks among health care workers: Results from the Duke Health and Safety Surveillance System. Am J Ind Med 2004;46(6):637-48.

4. Bozkurt S, Kökoğlu ÖF, Yanıt F, Kocahasanoğlu U, Okumuş $M$, Sucaklı $M H$, et al. Sağlık çalışanlarında iğne batması ve cerrahi aletlerle olan yaralanmalar. Dicle Med J 2013; 40(3):449-52.

5. Clarke SP. Hospital work environments, nurse characteristics, and sharps injuries. Am J Infect Control 2007;35(5):302-9. 
6. Panlilio AL, Orelien JG, Srivastava PU, Jagger J, Cohn RD, Carco DM, et al. Estimate of the annual number of percutaneous injuries among hospital-based healthcare workers in the United States, 1997-1998. Infect Control Hosp Epidemiol 2004;25(7):556-62.

7. Hastalık Kontrol ve Önleme Merkezi (Centers for Disease Control and Prevention, CDC). Workbook for designing, implementing, and evaluating a sharps injury prevention program 2015. Available from: http://www.cdc.gov/sharpssafety/pdf/sharpsworkbook 2008.pdf [Accessed 2015 Feb 15].

8. Kermode M, Jolley D, Langkham B, Thomas MS, Nick Crofts N. Occupational exposure toblood and risk of bloodborne virus infection among health care workers in rural North Indian healthcare settings. Am J Infect Control 2005;33(1):34-41.

9. Moro PL, Moore A, Balcacer P, Montero A, Diaz $D$, Gómez $V$, et al. Epidemiology of needlesticks and other sharps injuries and injection safety practices in the Dominican Republic. Am J Infect Control 2007;35(8):5529.

10. Gammon J, Morgan-Samuel H, Gould D. A review of the evidence for suboptimal compliance of healthcare practitioners to standard/universal infection control precautions. J Clin Nurs 2008;17(2):157-67.

11. Uzunbayır AN. Sağlık Çalışanlarının Kesici-Delici Tıbbi Aletleri Güvenli Kullanıma Yönelik Tutum Ölçeği. Ege Üniversitesi Sağlık Bilimleri Enstitüsü, İç Hastalıkları Hemşireliği Anabilim Dalı, Yüksek Lisans Tezi, 2009, İzmir.

12. Nagao $Y$, Baba $H$, Torii $K$, Nagao $M$, Hatakeyama $K$, linuma $Y$, et al. A long-term study of sharps injuries among health care workers in Japan. Am J Infect Control 2007;35(6):407-11.

13. Hastalık Kontrol ve Önleme Merkezi (Centers for Disease Control and Prevention, CDC). Guidelines for prevention of transmission of human immundeficiency virus and hepatitis-B virus to health-care and publicsafety workers. MMWR Morb Mortal Wkly Rep 1989;38(6):1-37.

14. Ferguson KJ, Waitzkin $\mathrm{H}$, Beekmann SE, Doebbeling BN. Critical incidents of nonadherencewith standard precautions guidelines among community hospital-based health care workers. J Gen Intern Med 2004;19(7):726-31.

15. Shiao JSC, Lin MS, Shih TS, Jagger J, Chen CJ. National incidence of percutaneous injury in Taiwan healthcare workers. Res in Nurs Health 2008;31(3):1729.

16. Rapparini C, Saraceni V, Lauria LM, Barroso PF, Vellozo V, Cruz $M$, et al. Occupational exposures to bloodborne pathogens among healthcare workers in Rio De Janeiro, Brazil. J Hosp Infect 2007;65(2):131-7.

17. Kişioğlu AN, Öztürk M, Uskun E, Kırbıyık S. Bir Üniversite Hastanesi sağlık personelinde kesici-delici yaralanma epidemiyolojisi ve korunmaya yönelik tutum ve davranışlar. Turkiye Klinikleri J Med Sci 2002;22(4):390-6

18. Hadadi A, Afhami S, Karbakhsh M, Esmailpour N. Occupational exposure to body Fluids among healthcare workers: A report from Iran. Singapore Med J 2008;49(6):492-6.

19.Yang Y, Wu MT, Ho CK, Chuang HY, Chen L, Yang $\mathrm{CY}$, et al. Needlestick/sharps injuries among vocational school nursingstudents in Southern Taiwan. Am J Infect Control 2004;32(8):431-5.

20. Uçan O, Ovayolu N, Torun S. Hemşirelerin hepatit $B$ ve $C$ virüslerinden korunmak için aldıkları önlemlerin belirlenmesi. Atatürk Üniversitesi Hemşirelik Yüksekokulu Dergisi 2006;9(2):45-56.

21. Yıldız K. Sağıık Çalışanlarının Kesici-Delici Aletleri Güvenli Kullanımlarının İncelenmesi. Ege Üniversitesi Sağlık Bilimleri Enstitüsü, İç Hastalıkları Hemşireliği Anabilim Dalı, Yüksek Lisans Tezi, 2011, İzmir.

22. Himmelreich $H$, Rabenau HF, Rindermann $M$, Stephan C, Bickel M, Marzi I, et al. The management of needlestick injuries. Dtsch Arztebl Int. 2013;110(5):61-7.

23. Sahio J, Gou L, McLaws M L. Estamination of the risk of blood borne pathogens to health care workers after a needlestick injury in Taiwan. Am J Infect Cont 2002;30(1):15-20.

24. Altıok M, Kuyurtar F, Karaçorlu S, Ersöz G, Erdoğan S. Sağlık çalışanlarının delici-kesici aletlerle yaralanma deneyimleri ve yaralanmaya yönelik alınan önlemler. Maltepe Üniversitesi Hemşirelik Bilim ve Sanatı Dergisi 2009;2(3):70-9.

25. Yacoub R, AlAli $R$, Moukeh $G$, Lahdo A, Mouhammad $Y$, Nasser $M$. Hepatitis B vaccination status and needlestick injuries among healthcare workers in Syria. J Glob Infect Dis 2010;2(1):28-34. 